\title{
PENGARUH PENENTUAN QUICK OF BLOOD (QB) TERHADAP KEBERHASILAN UREUM REDUCTION RATIO (URR) DENGAN LAMANYA HEMODIALISIS DI MURNI TEGUH MEMORIAL HOSPITAL
}

\author{
${ }^{1}$ Harsudianto Silaen, ${ }^{2}$ Yusrial Tarihoran \\ Dosen Prodi S1 Keperawatan, STIKes Murni Teguh, Jalan Jawa No 2 Gang Buntu Medan \\ E-mail: ${ }^{1}$ antosilaen4@gmail.com, ${ }^{2}$ yusrialtarihoran@gmail.com
}

\begin{abstract}
ABSTRAK
Proses perpindahan cairan darah pasien menuju dialiser ditentukan oleh kecepatan aliran darah. Kecepatan aliran darah (Quick of Blood/Qb) adalah jumlah darah yang dapat dialirkan dalam satuan waktu menit ( $\mathrm{mL} / m e n i t)$. Semakin banyak darah yang dapat dialirkan menuju dialiser dalam permenitnya maka semakin banyak zat-zat toksik dan cairan yang berlebih dapat dikeluarkan dari tubuh.Pengaturan Qb yang tepat dan sesuai dengan kondisi pasien sangat penting diperhatikan agar tercapai efisiensi proses hemodialisis. Berdasarkan studi pendahuluan, banyak ditemukan pasien hemodialisis yang menjalani hemodialisis lebih dari 4-5 jam akibat kelebihan cairan dan urea ratio reduction (URR) berlebih di dalam darah.Tujuan penelitian ini, ingin menganalisis pengaruh penentuan Quick of Blood $(Q b)$ terhadap keberhasilan Ureum Reduction Ratio (URR) dengan Lamanya Hemodialisis di Murni Teguh Memorial Hospital. Jenis penelitian ini adalah penelitian kuantitatif dengan metode QuasiExperimental Study dengan desain penelitian pre test-post test. Tehnik pengambilan sampel adalah total sampling sebanyak 160 pasien hemodialisa. Sebelum (pre-test) dan sebuah (post-test), pemberian intervensi, sebelum melakukan uji statistik, peneliti melakukan uji normalitas dengan metode analisis secara komputerisasi menggunakan kolmorogov-smirnovtest dengan nilai kemaknaan (p>0,05) sehingga peneliti menggunakan uji statistik adalah one sample t-test. Hasil penelitian ini akan menjadi standar rumah sakit dalam penentuan quick of blood $(Q b)$ sehingga lamanya hemodialisis tidak melebihi dari waktu yang ditentukan dan biaya operasional selama hemodialisis lebih efektif.
\end{abstract}

Kata Kunci: Quick of Blood (Qb), Keberhasilan Ureum Reduction Ratio (URR), Lamanya Hemodialisis.

\section{PENDAHULUAN}

Terapi alternatif lain pengganti ginjal yang lain seperti peritoneal dialisis dan transplantasi ginjal tetapi penderita gagal ginjal lebih banyak yang memilih hemodialysis. Proses perpindahan cairan darah pasien menuju dialiser ditentukan oleh kecepatan aliran darah. Kecepatan aliran darah (Quick of Blood/Qb) adalah jumlah darah yang dapat dialirkan dalam satuan waktu menit (mL/menit).Semakin banyak darah yang dapat dialirkan menuju dialiser dalam permenitnya maka semakin banyak zat-zat toksik dan cairan yang berlebih dapat dikeluarkan dari tubuh pasien.Pengontrolan pada pasien hemodialisis yang sesuai dengan kebutuhan pasien dapat dinilai dari adekuasi hemodialisis yang dicapai pasien hemodialysis(Kallenbach, et al, 2005).

Adekuasi hemodialisis secara kuantitatif dapat diukur dengan pemeriksaan Urea Reduction Ratio (URR) yang mengukur persentase jumlah ureum yang dibersihkan dalam sekali tindakan hemodialisis. Penghitungan nilai URR adalah cara yang paling sederhana dan mudah untuk mengukur adekuasi tindakan hemodialisis. Nilai dari URR sangat tergantung pada aliran cairan dialysate, quick of blood (Qb), jenis dan bahan dializer, pemakaian ulang dializer dan luas permukaan dialyzer.Nilai URR dalam satu kali tindakan hemodialisis yang direkomendasikan adalah minimal $65 \%$ (Kallenbach et al, 2005).

Hemodialisis merupakan terapi pengganti ginjal yang dilakukan 2-3 kali seminggu dengan lama waktu 4-5 jam, yang bertujuan untuk mengeluarkan sisa-sisa metabolisme protein dan mengoreksi gangguan keseimbangan cairan dan elektrolit. Proses terapi hemodialisis yang membutuhkan waktu selama 5 jam, umumnya akan menimbulkan stres fisik pada pasien setelah hemodialisis. Pasien akan merasakan kelelahan, sakit kepala dan keluar keringat dingin akibat tekanan darah 
yang menurun, sehubungan dengan efek hemodialisis. Ketergantungan pasien terhadap mesin hemodialisis seumur hidup, perubahan peran, kehilangan pekerjaan dan pendapatan merupakan stressor yang dapat menimbulkan depresi pada pasien hemodialisis dengan prevalensi 15\%-69\% (Septiwi, 2013).

Penelitian terdahulu yang dilakukan oleh Tarihoran (2019) juga telah memberikan gambaran mengenai Shaker Exercise yang dilakukan secara rutin akan menguatkan otot dan mempercepat penyembuhan sehingga dapat mengurangi stressor dan depresi.

Perawat memiliki keahlian dalam hal teori, ilmiah dan keterampilan klinis yang dapat mempengaruhi dan memfasilitasi kesehatan masyarakat melalui pendidikan pada pasien untuk merubah perilaku (Carison, 2010). Perawat memiliki andil yang cukup besar dalam hal merubah perilaku kesehatan pada pasien, misalnya kegemukan, pemakaian alkohol, program diet dan pembatasan cairan. Pada pasien dengan gagal ginjal kronis perlu pengaturan diet yang seksama guna mencegah berbagai komplikasi untuk meningkatkan kualitas hidup pasien gagal ginjal kronis yang menjalani hemodialisa.

Hasil penelitian Silaen (2018), pengaruh pemberian konseling dengan tingkat kecemasan pada pasien yang menjalani hemodialisis di Rumah Sakit Kota Medan, dimana penelitian didapatkan pengaruh pemberian konseling pada pasien hemodialisis dengan tingkat kecemasan, diperoleh bahwa nilai $p$ value 0.00 . Diharapkan kepada perawat untuk memberikan edukasi dan konseling kepada pasien hemodialisis yang sedang menjalani hemodialisis agar pasien merasa nyaman dan tidak cemas dan dapat menjaga berat badan pasien.

Pasien gagal ginjal kronik harus menjalani terapi hemodialisis sepanjang hidupnya. Proses hemodialisis dapat dilakukan dua hingga tiga kali dalam seminggu dalam tiga hingga lima jam setiap kali hemodialisis untuk dapat mempertahankan kadar urea, kreatinin, asam urat dan fosfat dalam dalam kadar normalwalaupun masih terlihat kelainan klinis berupa gangguan metabolisme akibat toksik uremi (Yuwono, 2014).
Rekomendasi yang dapat diberikan adalah pengaturan QB harus disesuaikan dengan berat badan predialisis. Perawat dialisis mengatur QB sesuai dengan berat badan dan harus mempertimbangkan kecepatan aliran darah pada akses vaskuler (Thomas, 2002).

Perawat memiliki peran yang penting dalam proses pelaksanaan hemodialisis mulai dari pre, intra maupun post hemodialisis. Peran perawat hemodialisis adalah sebagai care provider dan educator (Kallenbach et al, 2005). Perawat hemodialisis dituntut memiliki kemampuan dalam melakukan pemeriksaan fisik, mempersiapkan pasiendan mesin menjelang pelaksanaan hemodialisis. Perawat diharapkan mampumenangani komplikasi intra hemodialisis baik secara mandiri maupunkolaborasi dengan tim kesehatan lain.

Selama proses intra HD, perawat melakukan pemantauan dan pengaturan $\mathrm{Qb}$ dengan tujuan untuk mencapai efisiensi selama proses HD berlangsung.Perawat berkolaborasi dengan tim dokter dan laboran untuk mengetahuipencapaian adekuasi HD sebagai bentuk evaluasi terhadap tercapainya dosis HD yang telah diberikan. Kolaborasi dengan tim dokter terkait denganpencapaian adekuasi HD dan penentuan dosis pasien untuk HD berikutnyasedangkan kolaborasi dengan laboran terkait dengan pemeriksaan lab untukureum pre dan post HD (Kallenbach et $a l, 2005)$.

Pengaturan $\mathrm{Qb}$ pada tindakan hemodialisis di Murni Teguh Memorial Hospital sangat baiktermasuk mengatasi kondisi pasien dan aliran darah pada akses vaskuler pasien. Pengetahuan perawat tentang QB dan URRsudah baik sehingga sering pada proses tindakan hemodialisis tercapainya adekuasi hemodialisis. Kondisi pasien yang sangat bervariasi mengakibatkan pengaturan QB tiap pasien berbeda.Sesuai dengan standar Murni Teguh Memorial Hospital pencapaian URR minimal $70 \%$ dan $\mathrm{Qb}$ 200-300 mL/menit dengan lama hemodialisa 4-5 jam. Berdasarkan fenomena tersebut diatas peneliti tertarik untuk melakukan penelitian tantang perbedaan presentase URR diatas $70 \%$ dan ketepatan waktu lamanya hemodialisadi Unit Hemodialisa Murni Teguh Memorial Hospital. 


\section{METODE}

Tujuan penelitian ini, ingin menganalisis pengaruh penentuan Quick of Blood (Qb) terhadap keberhasilan Ureum Reduction Ratio (URR) dengan Lamanya Hemodialisis di Murni Teguh Memorial Hospital. Jenis penelitian ini adalah penelitian kuantitatif dengan metode QuasiExperimental Study dengan desain penelitian pretest-posttest. Tehnik pengambilan sampel adalah total sampling sebanyak 160 pasien hemodialisa. Sebelum (pre-test) dan sebuah (post-test), pemberian intervensi, sebelum melakukan uji statistik, peneliti melakukan uji normalitas dengan metode analisis secara komputerisasi menggunakan kolmorogovsmirnovtest dengan nilai kemaknaan $(\mathrm{p}>0,05)$ dengan hasil data tidak berdistribusi normal yaitu nilai $p$ value $=$ 0,00 sehingga peneliti menggunakan uji statistik adalah one sample t-test.

Terdapat 3 tahapan dalam proses pelaksanaan, yaitu 1) Tahap pertama : peneliti terlebih dahulu memberikan format data demografi untuk dapat diisi oleh responden, 2) Tahap kedua : peneliti, anggota peneliti, administrasi 1 dan 2 adalah perawat Murni Teguh Memorial Hospital melakukan pengukuran berat badan dengan menggunakan alat timbangan yang baru sehingga tidak perlu dilakukan kalibrasi, alat tekanan darah yang baru sehingga tidak perlu dilakukan kalibrasi, penentuan Quick of Blood serta menghitung URR setelah hemodialisa. Setelah dilakukan perbandingan data sebelum dan sesudah maka dapat menganalisis data univariat dan bivariat dengan menghubungkan antara variabel independent dan variabel dependent dengan memakai distribusi frekuensi pada sistem komputerisasi.

\section{HASIL}

\section{Analisa Univariat}

\section{Karakteristik Responden ( $\mathrm{N}=\mathbf{1 6 0})$}

Berdasarkan hasil penelitian yang diperoleh, umur pasien hemodialisa yang baru, 35-45 tahun yaitu sebanyak 30orang $(18,8 \%)$, umur $46-55$ tahun yaitu sebanyak 120orang $(75 \%)$ dan umur $>55$ tahun yaitu sebanyak 10orang $(6,2 \%)$. Pekerjaan pasien hemodialisa yang baru, PNS yaitu sebanyak 13orang $(8,1 \%)$, pekerjaan wirausaha yaitu sebanyak 123 orang $(76,9 \%)$ dan pekerjaan IRT yaitu sebanyak 16 orang (10\%) dan pekerjaan lain-lainnya sebanyak 8 orang (5\%). Pendidikan pasien hemodialisa yang baru, SD yaitu sebanyak tidak ada, pendidikan SMP yaitu sebanyak 12 orang (7,5\%) danpendidikan SMA yaitu sebanyak 138 orang $(86,3 \%)$ dan pendidikan Perguruan Tinggi sebanyak 10 orang $(6,2 \%)$.

Tabel 1. Gambaran umum Nilai URR sebelum dan sesudah hemodialisisdi Murni Teguh Memorial Hospital $(\mathrm{n}=160)$

\begin{tabular}{ll}
\hline Variabel & Rata-rata \pm SD Mean \\
\hline URR Sebelum & 204,41 \\
\hline URR Sesudah & 44,51 \\
\hline
\end{tabular}

Berdasarkan tabel diatas, bahwa hasil penelitian ini menujukkan bahwa rata-rata nilai URR sebelum hemodialisa sebesar 204,41 dan setelah hemodialisa sebesar 44,51 menujukkan adanya perbedaan yang sangat signifikan.

Ureum merupakan sampah organik dari sisa metabolisme tubuh yang tidak dapat dibersihkan oleh ginjal karena ginjal mengalami gangguan yang bias muncul saat fungsi ginjal dibawah 50\%. Salah satu tujuan proses hemodialisis adalah membuang nitrogen sebagai sisa dari proses metabolisme dalam tubuh Kadar ureum dalam darah dipengaruhi oleh asupan protein, katabolisme dan kemampuan reasorbsi tubular ginjal. Kadar ureum tidak bisa dijadikan ukuran tentang fungsi filtrasi ginjal. Hasil ureum setelah hemodialisis yang masih tinggi akan mengakibatkan beberapa masalah seperti malnutrisi yang akan berdampak pada penurunan kadar $\mathrm{Hb}$, mudah terinfeksi dan sistem kekebalan yang menurun (Daugirdas, Blake \& Ing , 2007).

Hasil penelitian Silaen \& Ramadhani (2019), bahwa pasien hemodialisa yang mengalami hipertensi perlu dilakukan pendampingan konseling agar dapat meminimalisir kekambuhan penyakit hipertensi dalam pengaturan diet sehingga kadar ureum didalam darah selama hemodialisa tidak terlalu banyak.

Tabel 2. Gambaran umum lamanya hemodialisis dan Quick of Blood $(\mathrm{Qb}) \mathrm{di}$ Murni Teguh Memorial Hospital ( $\mathrm{n}=160)$

\begin{tabular}{ll}
\hline Variabel & Rata-rata \pm SD Mean \\
\hline Lama hemodialisis & 4,391 \\
\hline Quick of Blood & 254,63 \\
\hline
\end{tabular}


Berdasarkan tabel diatas, bahwa hasil penelitian ini menujukkan rata-rata lamanya hemodialisa dengan ketepatan waktu 4,391 jam dengan kecepatan $\mathrm{Qb} 254,63 \mathrm{~mL} /$ menit. Penurunan kadar ureum saat proses hemodialisis dipengaruhi oleh jenis dan luas membran dialyzer, lama waktu hemodialisis, $\mathrm{QB}$, quick of dialysate, makan saat proses hemodialisis dan bekuan darah di dialyzer atau blood line. Hasil penelitian ini menunjukan bahwa pengaturan QB berperan penting dalam lamanya hemodialisis (Chowdhury dkk., 2011).

Hasil penelitian Silaen (2018), bahwa lamanya hemodialisa dengan tingkat kecemasan pada pasien yang menjalani hemodialisis akan sangat rentan mengalami kecemasan karena kurangnya edukasi serta konseling yang diberikan kepada pasien.

\section{Analisa Bivariat}

\section{Pengaruh Penentuan Quick of Blood (Qb)} terhadap Keberhasilan Urea

Tabel 3. Reduction Ratio (URR) dengan Lamanya Hemodialisis di Murni Teguh Memorial Hospital Medan ( $\mathrm{N}=160)$

Pengaruh Penentuan Quick of $p$ value

Blood (Qb) terhadap Keberhasilan

Urea Reduction Ratio (URR)

dengan LamanyaHemodialisis

Setelah dilakukan penentuan Quick 0,000

of Blood (Qb) selama hemodialisis

Berdasarkan tabel diatas diperoleh bahwa nilai $p$ value 0,000 . Nilai $\alpha<0,05$ maka dapat disimpulkan bahwa terdapat pengaruh yang signifikan antara penentuan Quick of Blood $(\mathrm{Qb})$ terhadap keberhasilan Urea Reduction Ratio (URR) dengan Lamanya Hemodialisis di Murni Teguh Memorial Hospital.

\section{PEMBAHASAN}

Dari hasil penelitian yang dilakukan peneliti dinyatakan bahwa didapatkan pengaruh yang signifikan antara penentuan Quick of Blood $(\mathrm{Qb})$ terhadap keberhasilan Urea Reduction Ratio (URR) dengan Lamanya Hemodialisis di Murni Teguh Memorial Hospital.

Nilai dari URR sangat tergantung pada aliran cairan dialysate, quick of blood (QB), jenis dan bahan dialyzer, pemakaian ulang dialyzer dan luas permukaan dialyzer.Zyga dan Sarafis (2009) juga menyebutkan bahwa nilai bersihan urea atau nilai RRU dipengaruhi oleh kecepatan aliran darah, kecepatan aliran dialysate, permabilitas membran dialyzer dan resirkulasi.

Tindakan hemodialisis bisa mencapai hasil yang maksimal apabila parameter adekuasi hemodialisa bisa tercapai semua.Salah satu parameter adekuasi tindakan hemodialisis adalah rasio reduksi ureum (RRU). RRU yang direkomendasikan oleh (National Kidney Foundation Disease Outcomes Quality Initiative / NKF DOQI, 2006) dan Persatuan Nefrologi Indonesia / PERNEFRI (2003) adalah minimal 65\%.

Sesuai dengan standar Murni Teguh Memorial Hospital pencapaian URR minimal $70 \%$ dan $\mathrm{Qb} \quad 200-300 \mathrm{~mL} /$ menit dengan lama hemodialisa 4-5 jam. Berdasarkan fenomena tersebut diatas peneliti tertarik untuk melakukan penelitian tantang perbedaan presentase URR diatas $70 \%$ dan ketepatan waktu lamanya hemodialisadi Unit Hemodialisa Murni Teguh Memorial Hospital.

Berdasarkan hasil penelitian ini menujukkan bahwa rata-rata nilai URR sebelum hemodialisa sebesar 204,41 dan setelah hemodialisa sebesar 44,51 dengan persentase $78,01 \%$ menujukkan adanya perbedaan yang sangat signifikan. Berdasarkan hasil penelitian ini menujukkan rata-rata lamanya hemodialisa dengan ketepatan waktu 4,391 jam dengan kecepatan Qb 254,63 mL/menit.

Kecukupan dosis hemodialisis diukur dengan istilah adekuasi hemodialisis. Adekuasi hemodialisis secara kuantitatif dapat diukur dengan pemeriksaan Urea Reduction Ratio (URR) yang mengukur persentase jumlah ureum yang dibersihkan dalam sekali tindakan hemodialisis (NKFK/DOQI, 2006).

Nilai URR yang sangat tinggi pada penelitian ini dapat disebabkan oleh kadar ureum yang menurun drastis. Penurunan kadar ureum tersebut dapat diakibatkan oleh faktor gangguan lain pada tubuh pasien, misalnya pada keadaan gagal hati, hidrasi berlebih, keseimbangan nitrogen negatif pada malnutrisi dan malabsorpsi (KD et all, 2002).

Hasil penelitian Armezya et al (2016), tentang pengaruh hemodialisis terhadap Urea Reduction Ratio pada pasien penyakit Ginjal Kronik Stadium V di RSUP Dr. M. Djamil Padang bahwa diperoleh kesimpulan rerata perbedaan ureum sebelum dan sesudah hemodialisis sebesar 71,54+21,76. 
Hasil analisis uji-t berpasangan didapatkan $\mathrm{p}$ $=0,0001$ maka dapat disimpulkan ada perbedaan yang signifikan pada kadar ureum sebelum dan sesudah hemodialisis. Hasil penelitian ini sejalan dengan penelitian yang telah dilaksanakan.

Proses konseling dapat memberikan manfaat bagi pasien antara lain membantu pasien untuk mengenali permasalahan kesehatan yang dihadapi dan membantu mengatasi masalah kesehatan pasien serta mendorong pasien untuk mencari dan memilih cara pemecahan masalah peningkatan berat badan sehingga penentuan Qb dapat dilakukan secara konstanta dan URR dapat di minimalisir (Cornelia, et al., 2013).

Hasil penelitian Rahayuwati, et al., (2017), tentang pemilihan metode menjalani hemodialisa sangat penting dan dibutuhkan konseling oleh ahli termasuk tenaga kesehatan seperti perawat dan dokter dapat memberikan informasi tentang diet yang dapat meningkat kadar ureum didalam darahselamamenjalani hemodialisa.

\section{KESIMPULAN}

Kesimpulan hasil penelitian ini adalah

a. Mayoritasumur 46-55 tahun yaitu sebanyak 120 orang (75)\%), pekerjaan wirausaha yaitu sebanyak 123 orang $(76,9 \%)$ dan pendidikan SMA yaitu sebanyak 138 orang $(86,3 \%)$

b. Terdapat Pengaruh Penentuan Quick of Blood $(\mathrm{Qb})$ terhadap Keberhasilan Urea Reduction Ratio (URR) dengan LamanyaHemodialisis.

\section{SARAN}

a. Rumah Sakit

Tetap menjaga kualitas pelayanan hemodialisis dengan ketentuan URR 70\% serta lama hemodialisis 4-5 jam.

b. Bagi Pendidikan keperawatan Hasil penelitian ini diharapkan dapat menjadi informasi tambahan dan masukan dalam pengembangan pendidikan keperawatan terhadap mengatasi peningkatan URR selama hemodialisis dengan intervensi keperawatan.

c. Bagi Peneliti Selanjutnya Diharapkan bagi peneliti selanjutnya untuk menambah variabel lain untuk melihat faktor yang terkait terhadap meningkatnya URR yang signifikan.

\section{DAFTAR PUSTAKA}

Carison, E. (2010). Impacting Health Through on the Joba Counseling: Role for Profesional Nurses. MEDSURG Nursing.

Cornelia., Sumedi, E., Anwar, I., Ramayulis, R., Iwaningsih, S., Kresnawan, T, et al. (2013). Konseling gizi. Jakarta: Penebar.

Chowdhury, N,S., Islam,F,M,M., Zafreen F., Begum B,A., Sultana N., Perveen ,S., Mahal, M. (2011). Effect of Surface Area of Dialyzer membrane on the Adequacy Haemodialysis. JAFMC Bangladesh, 2 (suppl, 7), 9-11.

Daugirdas, J.T., Blake, P.G., \& Ing, T.S. (2007). Handbook of dialysis. (4th Edition). Philadelphia: Lippincott.

Kallenbach, J.Z, Gutch, C.F., Stoner, M.H., \& Corca, A.L. (2005). Hemodialysis for nursesand dialysis personal (7th Edition). St Louis Missouri: Elsavier Mosby.

National Kidney Foundation Disease Outcomes Quality Initiative / NKF DOQI. (2006). Clinical Practice Guidelines and Clinical Practice Recommendations: Hemodialysis Adequacy, Peritoneal Dialysis Adequacy and Vascular. Access. Am J Kidney Dis 48 (suppl 1). S1-S322.

Rahayuwati, et al. (2017). Pilihan Pengobatan Pasien Kanker Payudara Masa Hemodialisa: Studi Kasus. Jurnal Keperawatan Indonesia, Volume 20 No.2, Juli 2017, hal 118-127 pISSN 1410-4490, eISSN 2354-9203 DOI: 10.7454/jki.v20i2.478.

Persatuan Nefrologi Indonesia / PERNEFRI (2003).

Septiwi, C. (2013). Pengaruh Breathing Exercise terhadap Level Fatique Pasien Hemodialisis di RSPAD Gatot Subroto Jakarta. Jurnal Keperawatan (The Soedirman Journal of Nursing). Volume 8, No. 1.

Silaen, Harsudianto. (2018). Pengaruh Pemberian Konseling dengan Tingkat Kecemasan pada Pasien yang Menjalani Hemodialisis di Rumah Sakit Kota Medan. Jurnal Keperawatan Ilmiah 
Imelda. Vol. 4, No. 1, Februari 2018, ISSN 2597-7172.

Silaen, Harsudianto. (2018). Hubungan Lamanya Hemodialisis dengan Tingkat Kecemasan pada Pasien yang Menjalani Hemodialisis di Rumah Sakit Kota Medan. Indonesian Trust Health Journal. Vol 1, No 1, November 2018.

Silaen, Harsudianto dan Ramadhani. (2019). Pengaruh Pemberian Konseling Pada Pasien Hemodialisa Dengan Tingkat Kekambuhan Penyakit Hipertensi Di Rumah Sakit Kota Medan. Jurnal Keperawatan Priority, Vol 2, No. 2, Juli 2019 ISSN 2614-4719.
Thomas, N. (2002). Renal nursing. (2nd Edition). London United Kingdom: Elsevier Science.

Yuwono, Imam Hadi. (2014). Pengaturan Kecepatan Aliran Darah (Quick Of Blood) Terhadap Rasio Reduksi Ureum Pada Pasien Penyakit Ginjal Kronik Yang Menjalani Hemodialisis Di Unit Hemodialisis RSUD Kota Semarang. Jurnal Keperawatan. Vol. 7 No. 2 Oktober $2014: 130$ - 141.

Zyga. S. \& Sarafis, P. (2009). Haemodialysis Adequacy. Health Science Journal. 3 (suppl 4) 209-213.

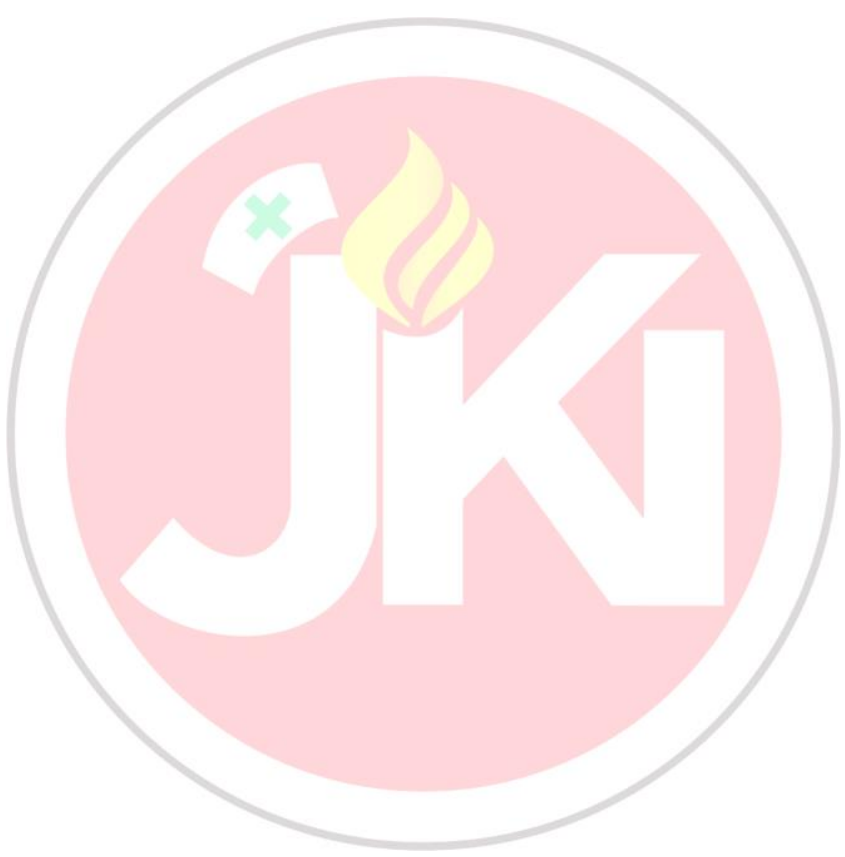

